\title{
Things We Do for No Reason: Prescribing Docusate for Constipation in Hospitalized Adults
}

\author{
Robert J Fakheri, MD*, Frank M Volpicelli, MD²
}

${ }^{1}$ Weill Cornell Medicine, New York, New York; ${ }^{2}$ NYU Langone Health, New York, New York.

The "Things We Do for No Reason" (TWDFNR) series reviews practices that have become common parts of hospital care but which may provide little value to our patients. Practices reviewed in the TWDFNR series do not represent "black and white" conclusions or clinical practice standards but are meant as a starting place for research and active discussions among hospitalists and patients. We invite you to be part of that discussion.

\section{CASE PRESENTATION}

An 80-year-old woman with no significant past medical history presents with a mechanical fall. X-rays are notable for a right hip fracture. She is treated with morphine for analgesia and evaluated by orthopedic surgery for surgical repair. The hospitalist recognizes that this patient is at high risk for constipation and orders docusate for prevention of constipation.

\section{BACKGROUND}

Constipation is a highly prevalent problem in all practice settings, especially in the hospital, affecting two out of five hospitalized patients. ${ }^{1}$ Multiple factors in the inpatient setting contribute to constipation, including decreased mobility, medical comorbidities, postsurgical ileus, anesthetics, and medications such as opioid analgesics. Furthermore, the inpatient population is aging in parallel with the general population and constipation is more common in the elderly, likely owing to a combination of decreased muscle mass and impaired function of autonomic nerves. ${ }^{2}$ Consequently, inpatient providers frequently treat constipation or try to prevent it using stool softeners or laxatives.

One of the most commonly prescribed agents, regardless of medical specialty, is docusate, also known as dioctyl sulfosuccinate or by its brand name, Colace. A study from McGill University Health Centre in Montreal, Canada reported that docusate was the most frequently prescribed laxative, accounting for $64 \%$ of laxative medication doses, with associated costs approaching $\$ 60,000$ per year. ${ }^{3}$ Direct drug costs accounted for a quarter of the expenses, and the remaining three quarters were estimated labor costs for administration. Medical and sur-

*Corresponding Author: Robert J. Fakheri, MD, Telephone: 646-962-9122; E-mail: robert.fakheri@gmail.com

Received: March 31, 2018; Revised: October 13, 2018;

Accepted: November 8, 2018

() 2019 Society of Hospital Medicine DOI 10.12788/jhm.3124 gical admissions shared similar proportions of usage, with an average of 10 doses of docusate per admission across 17,064 admissions. Furthermore, half of the patients were prescribed docusate upon discharge. The authors extrapolated their data to suggest that total healthcare spending in North America on docusate products likely exceeds $\$ 100,000,000$ yearly. A second study from Toronto found that $15 \%$ of all hospitalized patients are prescribed at least one dose of docusate, and that one-third of all new inpatient prescriptions are continued at discharge. $^{4}$

\section{WHY YOU THINK DOCUSATE MIGHT BE HELPFUL FOR CONSTIPATION}

Docusate is thought to act as a detergent to retain water in the stool, thereby acting as a stool softener to facilitate stool passage. Physicians have prescribed docusate for decades, and attendings have passed down the practice of prescribing docusate for constipation to medical trainees for generations. The initial docusate studies showed promise, as it softened the stool by increasing its water content and made it easier to pass through the intestines. ${ }^{5}$ One of the earliest human studies compared docusate to an unspecified placebo in 35 elderly patients with chronic atonic constipation and found a decreased need for enemas. ${ }^{6}$ Some other observational studies also reported a decreased need for manual disimpactions and enemas in elderly populations.,8 One randomized, controlled trial from 1968 showed an increased frequency of bowel movements compared to placebo, but it excluded half of the enrolled patients because they had a positive placebo response. ${ }^{9}$ Since those early studies from the 1950s and 1960s, docusate remains widely accepted as an effective stool softener with positive endorsements from hospital formularies and order sets and patient information sheets such as the JAMA Patient Page. ${ }^{10}$ Furthermore, the World Health Organization lists docusate as an "essential medicine," reinforcing the notion that it is effective. ${ }^{11}$

\section{WHY THERE IS NO REASON TO PRESCRIBE DOCUSATE FOR CONSTIPATION}

Despite common practice, the efficacy of docusate as a stool softener has not been borne out by rigorous scientific data. On the contrary, multiple randomized controlled trials have failed to show any significant efficacy of this drug over placebo (Table).

The initial trial in 1976 studied 34 elderly patients on a general medical ward for prophylaxis of constipation. ${ }^{12}$ They random- 
TABLE. Summary of Randomized Controlled Trials Studying Docusate

\begin{tabular}{|c|c|c|c|c|c|c|c|c|c|c|}
\hline First Author & $\begin{array}{c}\text { Year } \\
\text { Published }\end{array}$ & $\begin{array}{l}\text { Sample } \\
\text { Size (n) }\end{array}$ & $\begin{array}{l}\text { Patient } \\
\text { Population }\end{array}$ & $\begin{array}{l}\text { Intent of } \\
\text { Therapy }\end{array}$ & Site of Care & Docusate Dose & Comparator & Duration & Brief Summary & Comments \\
\hline Hyland ${ }^{9}$ & 1968 & 15 & $\begin{array}{l}\text { Geriatric patients in } \\
\text { hospital with chronic } \\
\text { constipation }\end{array}$ & Treatment & Hospital & $\begin{array}{l}\text { Docusate sodium } \\
100 \mathrm{mg} \text { tid }\end{array}$ & $\begin{array}{l}\text { Placebo with } \\
\text { crossover }\end{array}$ & $\begin{array}{l}\text { Four weeks, } \\
\text { then four } \\
\text { weeks } \\
\text { crossover }\end{array}$ & $\begin{array}{l}\text { Increase in bowel movements } \\
\text { with treatment }\end{array}$ & $\begin{array}{l}19 \text { patients excluded } \\
\text { because of placebo } \\
\text { response }\end{array}$ \\
\hline$G$ oodman ${ }^{12}$ & 1976 & 34 & $\begin{array}{l}\text { Prophylaxis for } \\
\text { Inpatients on "chronic } \\
\text { medical service" }\end{array}$ & Prophylaxis & Hospital & $\begin{array}{l}\text { Docusate sodium } \\
100 \mathrm{mg} \text { bid }\end{array}$ & Control & 26 days & $\begin{array}{l}\text { No difference in frequency } \\
\text { of quality of bowel movements }\end{array}$ & \\
\hline Fain $^{13}$ & 1978 & 46 & $\begin{array}{l}\text { Institutionalized } \\
\text { patients with chronic } \\
\text { constipation }\end{array}$ & Treatment & Nursing home & $\begin{array}{l}\text { Docusate sodium } \\
100 \mathrm{mg} \text { daily, } \\
\text { docusate sodium } \\
100 \mathrm{mg} \text { bid, } \\
\text { docusate calcium } \\
240 \text { mg daily }\end{array}$ & $\begin{array}{l}\text { Placebo period } \\
\text { for each arm }\end{array}$ & $\begin{array}{l}\text { Two weeks } \\
\text { placebo, } \\
\text { three weeks } \\
\text { treatment }\end{array}$ & $\begin{array}{l}\text { An increase in frequency of bowel } \\
\text { movements with docusate calcium } \\
240 \text { mg, but no change in quality. } \\
\text { Increase in bowel movements in } \\
\text { other arms did not meet statistical } \\
\text { significance }\end{array}$ & \\
\hline Chapman $^{14}$ & 1985 & 12 & $\begin{array}{l}\text { Healthy patients } \\
\text { with ileostomies and } \\
\text { healthy controls }\end{array}$ & Prophylaxis & Ambulatory & $\begin{array}{l}\text { Docusate sodium } \\
100 \mathrm{mg} \text { tid }\end{array}$ & $\begin{array}{l}\text { Control with } \\
\text { crossover }\end{array}$ & Four days & $\begin{array}{l}\text { No difference in stool weight, } \\
\text { frequency, water content, or transit } \\
\text { time }\end{array}$ & \\
\hline Castle $^{15}$ & 1991 & 15 & $\begin{array}{l}\text { Elderly veterans in } \\
\text { nursing home on } \\
\text { bowel regimen }\end{array}$ & Treatment & Nursing home & $\begin{array}{l}\text { Docusate calcium } \\
240 \mathrm{mg} \text { bid }\end{array}$ & $\begin{array}{l}\text { Placebo with } \\
\text { crossover }\end{array}$ & $\begin{array}{l}\text { Three weeks } \\
\text { then two } \\
\text { weeks } \\
\text { crossover }\end{array}$ & $\begin{array}{l}\text { No difference in stool frequency, } \\
\text { need for additional laxatives, or } \\
\text { patient's subjective experience }\end{array}$ & \\
\hline McRorie $^{17}$ & 1998 & 170 & $\begin{array}{l}\text { Chronic idiopathic } \\
\text { constipation }\end{array}$ & Treatment & Ambulatory & $\begin{array}{l}\text { Docusate sodium } \\
100 \mathrm{mg} \text { bid }\end{array}$ & $\begin{array}{l}\text { Psyllium } 5.1 \mathrm{~g} \\
\text { bid }\end{array}$ & $\begin{array}{l}\text { Two weeks } \\
\text { placebo, } \\
\text { two weeks } \\
\text { treatment }\end{array}$ & $\begin{array}{l}\text { Psyllium increased stool water } \\
\text { content and frequency; docusate } \\
\text { had no change }\end{array}$ & Industry sponsored \\
\hline Tarumi $i^{18}$ & 2013 & 74 & Hospice patients & $\begin{array}{l}\text { Prophylaxis } \\
\text { and treatment }\end{array}$ & $\begin{array}{l}\text { Inpatient } \\
\text { hospice }\end{array}$ & $\begin{array}{l}\text { Docusate sodium } \\
200 \mathrm{mg} \text { bid }\end{array}$ & Placebo & 10 days & $\begin{array}{l}\text { No difference in stool frequency, } \\
\text { volume, or consistency }\end{array}$ & $\begin{array}{c}\text { All patients received } \\
\text { sennosides }\end{array}$ \\
\hline
\end{tabular}

ized patients to $100 \mathrm{mg}$ twice daily of docusate sodium versus a control group that did not receive any type of laxative. The number of bowel movements and their character served as the measured outcomes. The study demonstrated no statistically significant differences in the frequency and character of bowel movements between the docusate and placebo groups. Even at that time, the authors questioned whether docusate had any efficacy at all: "[w]hether the drug actually offers anything beyond a placebo effect in preventing constipation is in doubt."

Another trial in 1978 studied 46 elderly, institutionalized patients with chronic functional constipation. ${ }^{13}$ All patients underwent a two-week placebo period followed by a three-week treatment period with three arms of randomization: docusate sodium $100 \mathrm{mg}$ daily, docusate sodium $100 \mathrm{mg}$ twice daily, or docusate calcium $240 \mathrm{mg}$ daily. Patients received enemas or suppositories if required. All three arms showed an increase in the average number of natural bowel movements when compared to each patient's own placebo period, but only the arm with docusate calcium reached statistical significance $(P<.02)$. According to the authors, none of the therapies appeared to have a significant effect on stool consistency. The authors hypothesized that the higher dose given to the docusate calcium arm may have been the reason for the apparent efficacy in this cohort. As such, studies with higher doses of docusate calcium would be reasonable.

A third study in 1985 compared docusate sodium $100 \mathrm{mg}$ three times daily versus placebo in six healthy patients with il- eostomies and six healthy volunteers. ${ }^{14}$ Therapy with docusate "had no effect on stool weight, stool frequency, stool water, or mean transit time."

Another study in 1991 evaluated 15 elderly nursing home residents with a randomized, double-blind crossover design. ${ }^{15}$ Subjects received $240 \mathrm{mg}$ twice daily of docusate calcium versus placebo for three weeks and then crossed over to other arm after a two-week wash-out period. The investigators found no difference in the number of bowel movements per week or in the need for additional laxatives between the two study periods. There were also no differences in the patients' subjective experience of constipation or discomfort with defecation.

Larger studies were subsequently initiated in more recent years. In 1998, a randomized controlled trial in 170 subjects with chronic idiopathic constipation compared psyllium $5.1 \mathrm{~g}$ twice daily and docusate sodium $100 \mathrm{mg}$ twice daily with a corresponding placebo in each arm for a treatment duration of two weeks after a two-week placebo baseline period. ${ }^{16}$ Psyllium was found to increase stool water content and stool water weight over the baseline period, while docusate essentially had no effect on stool water content or water weight. Furthermore, by treatment week 2, psyllium demonstrated an increase in the frequency of bowel movements, whereas docusate did not. It should be noted that this study was funded by Procter \& Gamble, which manufactures Metamucil, a popular brand of psyllium.

Lastly, the most recent randomized controlled trial was published in 2013. It included 74 hospice patients in Canada, 
comparing docusate $200 \mathrm{mg}$ and sennosides twice daily versus placebo and sennosides for 10 days. The study found no difference in stool frequency, volume, or consistency between docusate and placebo. ${ }^{17}$

A number of systematic reviews have studied the literature on bowel regimens and have noted the paucity of high-quality data supporting the efficacy of docusate, despite its widespread use. ${ }^{18-22}$ With these weak data, multiple authors have advocated for removing docusate from hospital formularies and using hospitalizations as an opportunity to deprescribe this medication to reduce polypharmacy. ${ }^{3,4,23}$

Although docusate is considered a benign therapy, there is certainly potential for harm to the patient and detrimental effects on the healthcare system. Patients commonly complain about the unpleasant taste and lingering aftertaste, which may lead to decreased oral intake and worsening nutritional status. ${ }^{23}$ Furthermore, docusate may impact the absorption and effectiveness of other proven treatments. ${ }^{23}$ Perhaps the most important harm is that providers needlessly wait for docusate to fail before prescribing effective therapies for constipation. This process negatively impacts patient satisfaction and potentially increases healthcare costs if hospital length of stay is increased. Another important consideration is that patients may refuse truly necessary medications due to the excessive pill burden.

Costs to the healthcare system are increased needlessly when medications that do not improve outcomes are prescribed. Although the individual pill cost is low, the widespread use and the associated pharmacy and nursing resources required for administration create an estimated cost for docusate over $\$ 100,000,000$ per year for North America alone. ${ }^{3}$ The staff time required for administration may prevent healthcare personnel from engaging in other more valuable tasks. Additionally, every medication order creates an opportunity for medical error. Lastly, bacteria were recently found contaminating the liquid formulation, which carries its own obvious implications if patients develop iatrogenic infections. ${ }^{24}$

\section{WHAT YOU SHOULD DO INSTEAD}

Instead of using docusate, prescribe agents with established efficacy. In 2006, a systematic review published in the American Journal of Gastroenterology graded the evidence behind different therapies for chronic constipation. ${ }^{21}$ They found good evidence (Grade A) to support the use of polyethylene glycol (PEG), while psyllium and lactulose had moderate evidence (Grade B) to support their use. All other currently available agents that were reviewed had poor evidence to support their use. A more recent study in people prescribed opioids similarly found evidence to support the use of polyethylene glycol, lactulose, and sennosides. ${ }^{25}$ Lastly, the 2016 guidelines from the American Society of Colon and Rectal Surgeons do not mention docusate, though they comment on the paucity of data on stool softeners. Their recommendations for laxative therapy are similar to those of the previously discussed reviews. ${ }^{26}$ Ultimately, the choice of therapy, pharmacological and nonpharmacological, should be individualized for each patient based on the clinical context and cause of constipation. Non- pharmacologic treatments include dietary modification, mobilization, chewing gum, and biofeedback. If pharmacotherapy is required, use laxatives with the strongest evidence.

\section{RECOMMENDATIONS}

- In patients with constipation or at risk for constipation, use laxatives with proven efficacy (such as polyethylene glycol, lactulose, psyllium, or sennosides) for treatment or prophylaxis of constipation instead of using docusate.

- Discuss de-prescription for patients using docusate prior to admission.

- Remove docusate from your hospital formulary.

\section{CONCLUSION}

Docusate is commonly used for the treatment and prevention of constipation in hospitalized patients, with significant associated costs. This common practice continues despite little evidence supporting its efficacy and many trials failing to show benefits over placebo. Decreased utilization of ineffective therapies such as docusate is recommended. Returning to the case presentation, the hospitalist should start the patient on alternative therapies, instead of docusate, such as polyethylene glycol, lactulose, psyllium, or sennosides, which have better evidence supporting their use.

Do you think this is a low-value practice? Is this truly a "Thing We Do for No Reason?" Share what you do in your practice and join in the conversation online by retweeting it on Twitter (\#TWDFNR) and liking it on Facebook. We invite you to propose ideas for other "Things We Do for No Reason" topics by emailingTWDFNR@hospitalmedicine.org.

Disclosures: All authors deny any relevant conflict of interest with the attached manuscript.

\section{References}

1. Noiesen E, Trosborg I, Bager L, Herning M, Lyngby C, Konradsen H. Constipation--prevalence and incidence among medical patients acutely admitted to hospital with a medical condition. J Clin Nurs. 2014;23(15-16):2295-2302. doi: 10.1111/jocn.12511.

2. De Giorgio R, Ruggeri E, Stanghellini V, Eusebi LH, Bazzoli F, Chiarioni G. Chronic constipation in the elderly: a primer for the gastroenterologist. BMC Gastroenterol. 2015;15:130. doi: 10.1186/s12876-015-0366-3.

3. Lee TC, McDonald EG, Bonnici A, Tamblyn R. Pattern of inpatient laxative use: waste not, want not. JAMA Intern Med. 2016;176(8):1216-1217. doi: 10.1001/jamainternmed.2016.2775

4. MacMillan TE, Kamali R, Cavalcanti RB. Missed opportunity to deprescribe: docusate for constipation in medical inpatients. Am J Med. 2016;129(9):1001 e1001-1007. doi: 10.1016/j.amjmed.2016.04.008.

5. Spiesman MG, Malow L. New fecal softener (doxinate) in the treatment of constipation. J Lancet. 1956;76(6):164-167.

6. Harris R. Constipation in geriatrics; management with dioctyl sodium sulfosuccinate. Am J Dig Dis. Sep 1957;2(9):487-492.

7. Smigel JO, Lowe KJ, Hosp PH, Gibson JH. Constipation in elderly patients; treatment with dioctyl sodium sulfosuccinate and dioctyl sodium sulfosuccinate plus peristim. Med Times. 1958;86(12):1521-1526.

8. Wilson JL, Dickinson DG. Use of dioctyl sodium sulfosuccinate (aerosol O.T.) for severe constipation. J Am Med Assoc. 1955;158(4):261-263. doi: 10.1001/ jama.1955.02960040019006a.

9. Hyland CM, Foran JD. Dioctyl sodium sulphosuccinate as a laxative in the elderly. Practitioner. 1968;200(199):698-699. 
10. Jin J. JAMA patient page. Over-the-counter laxatives. JAMA. 2014;312(11): 1167. doi: 10.1001/jama.2014.2078.

11. 19th WHO Model List of Essential Medicines (April 2015). 2015; http://www. who.int/medicines/publications/essentialmedicines/en/.

12. Goodman J, Pang J, Bessman AN. Dioctyl sodium sulfosuccinate- an ineffective prophylactic laxative. J Chronic Dis. 1976;29(1):59-63. doi: 10.1016/0021 9681(76)90068-0.

13. Fain AM, Susat R, Herring M, Dorton K. Treatment of constipation in geriatric and chronically ill patients: a comparison. South Med J. 1978;71(6):677-680.

14. Chapman RW, Sillery J, Fontana DD, Matthys C, Saunders DR. Effect of ora dioctyl sodium sulfosuccinate on intake-output studies of human small and large intestine. Gastroenterology. 1985;89(3):489-493. doi: 10.1016/00165085(85)90441-X.

15. Castle SC, Cantrell M, Israel DS, Samuelson MJ. Constipation prevention: empiric use of stool softeners questioned. Geriatrics. 1991;46(11):84-86.

16. McRorie JW, Daggy BP, Morel JG, Diersing PS, Miner PB, Robinson M Psyllium is superior to docusate sodium for treatment of chronic constipation. Aliment Pharmacol Ther. 1998;12(5):491-497. doi: 10.1046/j.13652036.1998.00336.x.

17. Tarumi Y, Wilson MP, Szafran O, Spooner GR. Randomized, double-blind, placebo-controlled trial of oral docusate in the management of constipation in hospice patients. J Pain Symptom Manage. 2013;45(1):2-13. doi: 10.1016/j. jpainsymman.2012.02.008.

18. Candy B, Jones L, Larkin PJ, Vickerstaff V, Tookman A, Stone P. Laxatives for the management of constipation in people receiving palliative care. Co- chrane Database Syst Rev. 2015(5):CD003448.

19. Hurdon V, Viola R, Schroder C. How useful is docusate in patients at risk for constipation? A systematic review of the evidence in the chronically ill. J Pain Symptom Manage. 2000;19(2):130-136. doi: 10.1016/S0885-3924(99)00157-8.

20. Pare P, Fedorak RN. Systematic review of stimulant and nonstimulant laxatives for the treatment of functional constipation. Can J Gastroenterol Hepatol. 2014;28(10):549-557.

21. Ramkumar D, Rao SS. Efficacy and safety of traditional medical therapies for chronic constipation: systematic review. Am J Gastroenterol. 2005;100(4):936971. doi: 10.1111/j.1572-0241.2005.40925.x

22. Health CAfDaTi. Dioctyl sulfosuccinate or docusate (calcium or sodium) for the prevention or management of constipation: a review of the clinical effectiveness. Ottawa (ON)2014.

23. McKee KY, Widera E. Habitual prescribing of laxatives-it's time to flush outdated protocols down the drain. JAMA Intern Med. 2016;176(8):1217-1219. doi: 10.1001/jamainternmed.2016.2780.

24. Marquez L, Jones KN, Whaley EM, et al. An outbreak of burkholderia cepacia complex infections associated with contaminated liquid docusate. Infect Control Hosp Epidemiol. 2017;38(5):567-573. doi: 10.1017/ice.2017.11.

25. Ahmedzai SH, Boland J. Constipation in people prescribed opioids. BMJ Clin Evid. 2010;2010.

26. Paquette IM, Varma M, Ternent $C$, et al. The American society of colon and rectal surgeons' clinical practice guideline for the evaluation and management of constipation. Dis Colon Rectum. 2016;59(6):479-492. doi: 10.1097/ DCR.0000000000000599 